\title{
Bark of Siberian Conifers: Composition, Use, and Processing to Extract Tannin
}

\author{
Vladimir S. Fedorov* $*$ and Tatyana V. Ryazanova
}

Citation: Fedorov, V.S.;

Ryazanova, T.V. Bark of Siberian Conifers: Composition, Use, and Processing to Extract Tannin. Forests 2021, 12, 1043. https://doi.org/ $10.3390 /$ f12081043

Academic Editor: Miha Humar

Received: 30 June 2021

Accepted: 3 August 2021

Published: 5 August 2021

Publisher's Note: MDPI stays neutral with regard to jurisdictional claims in published maps and institutional affiliations.

Copyright: (c) 2021 by the authors. Licensee MDPI, Basel, Switzerland. This article is an open access article distributed under the terms and conditions of the Creative Commons Attribution (CC BY) license (https:/ / creativecommons.org/licenses/by/ $4.0 /)$.
Department of Chemical Technology of Wood and Biotechnology, Reshetnev Siberian State University of Science and Technology, 660037 Krasnoyarsk, Russia; tatyana-htd09@mail.ru

* Correspondence: FedorovVladimir1996@yandex.ru

\begin{abstract}
The rational use of natural resources, including the creation of new and improvement of existing technologies in order to reduce the anthropogenic impact on the environment, is currently an important task. This review covers different methods of softwood bark processing. Bark is used for the production of heat-insulating plates, and also as filler in adhesives and composites. In agriculture, it is used as a mulch. Softwood bark is a valuable raw material for chemical processing. Extractive substances of the bark are of particular interest. Among them, phenolic compounds are very important, in particular of tannin nature, which are used as tanning agents in leather production. Bark is used for the isolation of substances with antibacterial activity for pharmaceutical and nutraceutical applications. Aqueous-alkaline solutions, in particular monoethanolamine, are used as an extracting agent. Currently, tannins have been applied into many different fields, including medicine, food, beverage, the manufacture of ink and adhesives, the dye and tanning industry, plastic resins, water purification, and surface coatings. Tanning extracts obtained as a result of extraction are refined by ultrafiltration. The obtained extracts are of high purity. The extraction residue, the so-called tan, is a promising raw material for obtaining a cellulosic product. In addition to the chemical conversion of tan, biotechnological processing is an alternative option. In the process of tan biodegradation by the microscopic Trichoderma fungus, a biological product trichodermin is obtained, which is used to protect plants from phytopathogens.
\end{abstract}

Keywords: softwood bark; chemical composition; extraction; tanning extract; tannin refinement; ultrafiltration; tan; delignification; biodegradation

\section{Introduction}

Forests are the dominant terrestrial ecosystem on Earth, accounting for $31 \%$ of the total land area [1]. The world's forested area is 4.06 billion hectares. Tree growing is the main task of forestry, as a result of which a large amount of renewable raw materials are produced annually. Most of the world's forests (54\%) are located in the Russian Federation (815 million hectares), Brazil (497 million hectares), Canada (347 million hectares), the United States of America (310 million hectares), and China (220 million hectares), according to the data provided by the Food and Agriculture Organization of the United Nations (FAO) for 2020 [1].

The Krasnoyarsk Territory is $69.3 \%$ covered with forests and is one of the leading forested regions in the Russian Federation. The total forest resources of the Krasnoyarsk Territory amount to 164 million hectares [2]. The main forest-forming species in the Krasnoyarsk Territory are conifers; they occupy more than $75.9 \%$ of the forested area, which amounts to 9.7 billion $\mathrm{m}^{3}$; the share of spruce and fir amounts to $16.0 \%$ (1.6 billion $\mathrm{m}^{3}$ ) [3].

The most important feature of Siberian forests is the preservation of natural plantations in large areas that are relatively weakly exposed to human anthropogenic impact. Forest ecosystems have a natural (background) level of biodiversity and represent standards for population, species, and ecosystem diversity. These forests are fundamentally 
different from the "cultivated" forests represented in Western Europe and Russia by artificial plantations with reduced resistance to adverse environmental factors and climatic conditions [4].

The annual conifer felling volume in the Krasnoyarsk Territory is 48.9 million $\mathrm{m}^{3}$. The total weight of wood used from the total volume of harvested wood is $75 \%$. The share of bark is $6-15 \%$ and the share of foliage is $10-20 \%$. The crown, a part of the trunk, top, twigs, stumps, roots, and some foliage are left in the felling area as logging waste. The amount of such waste varies from $30 \%$ to $50 \%$ of the total biomass $[5,6]$.

Plant waste is a major source of environmental pollution. Millions of tonnes lay sitting in dumps for many years, creating additional pressure on the environment, as the bark decomposes slowly under natural conditions. In summer, bark dumps pose a fire hazard. In addition, dumping territories are excluded from the economic turnover. Burning the bark is not cost-effective due to its low heating value and its high ash and moisture content. It partially decomposes when stored for a long time, forming phenolic compounds, which are washed off by precipitation and meltwater. Pollution of the environment by these compounds can lead to disruption of the biological balance between individual links of biogeocenoses and thereby cause great damage to the national economy. At the same time, tree bark contains valuable extractives, and large-tonnage bark waste is a huge raw material resource for manufacturing expensive chemical products [7]. The problem of wood waste recycling is a weak point in integrated raw material processing [8-11].

\section{Use of Coniferous Bark}

Despite the high content of tanning substances in bark, barking waste from pulp and paper plants and wood processing plants is not used as raw material for tanning agents production due to the high content of wood impurities (up to 30\%). This raw material composition leads to a decrease in quality of obtained extracts.

Tree bark performs many functions during a plant's life: it preserves the cambium, covers the trunk, branches, and roots, thereby protecting against harmful microorganisms and preventing water loss, and also plays an important role in the event of fires [12-15]. Bark fire resistance depends on its thickness and moisture content. Bark anatomy depends on species, age, place of growth, and ecology [16].

Tree bark can be considered a biological indicator since, due to its porous structure, it is always subject to pollution from harmful air emissions [17-21]. It has been found that the quantitative content of phenolic compounds, waxes, tannins, and pectin substances in the Siberian and Dahurian larch bark is significantly affected by technogenic factors. The increased content of phenolic compounds is evidence of the development of plant defense mechanisms against growing conditions [22].

A modified type of bark is used for air purification as a biofilter, as well as for water purification, which allows for the binding of poisonous ions of lead, cadmium, mercury, and zinc [23].

Bark can be considered a lignocellulosic waste [24] that can be recycled as a substrate for anaerobic fermentation.

Conifers are used to obtain biologically active polyphenols, in particular, dihydroquercetin and dihydrokaempferol products $[25,26]$. It is also possible to obtain a natural antioxidant complex based on phenolic compounds that has a number of properties, such as hepatoprotection, capillary protection, and antioxidant activity [27]. Currently, such complex is used as a biologically active additive (BAA) Picnolar. There is evidence for the ability to obtain pectins from larch bark, which are used in the food industry as a gelling agent, as well as in pharmaceuticals for removing radionuclides from the human body [28].

Bark is used to obtain substances with bactericidal and hydrophobic properties, such as wax, which is widely used in the cosmetic industry. Larch bark is used in traditional medicine as extracts that have diuretic properties, and ointments are used for healing wounds, as well as chronic eczema and psoriasis [29]. 
In addition to the above, bark is a good lignin-carbohydrate complex that can be used as a sorbing agent for collecting oil products from the surface of polluted water bodies.

Fir bark is used to obtain effective carbon sorbents using thermos-elastic activation in the presence of potassium hydroxide [30]. Enterosorbents obtained from crushed fir bark by treating it with a $1.5 \%$ aqueous solution of $\mathrm{NaOH}$ and hexane have good sorption properties [31]. The softwood bark post-extraction residue can be treated with modifiers, for example, the PMS-100 polymethylsalaxane liquid. At the same time, it has been found that the modified bark can retain hydrocarbon materials. The maximum hydrophobization efficiency was achieved for larch and pine bark [32].

Bark can be used in new lignocellulosic composites [33]. Crushed bark is used as a filler in polylactic acid (PLA) composites, which have higher strength indicators and low moisture resistance compared to High Density Polyethylene (HDPE) composites [34]. In thermoplastic polymers, tree bark can be considered a filler, which leads to an increased heat capacity and thermal conductivity [35].

Bark is successfully used as an innovative raw material to create effective environmentally friendly insulation materials [36,37]. When using bark to obtain panels associated with tannin, the level of free formaldehyde is reduced [38,39]. It is known that to increase the fire resistance of the composite, larch bark is mixed with clay [40].

Bark water extracts can be successfully used in glue production. The hydroxyl groups of phenolic substances interact with formaldehyde and form a binding base, which is used for the production of waterproof chipboard and plywood [41,42].

The use of bark in agriculture for mulching reduces evaporation from the soil surface. Due to the mulch decomposition duration, soil needs less additional artificial fertilizers; it also contributes to aeration [43].

\section{Chemical Composition of Coniferous Bark}

Softwood bark is an abundant and inexpensive waste of the agro-industrial complex, which allows it to be used as a raw material for chemical processing. The relative volume of bark in the trunk for different species of conifers is as follows: larch $22-25 \%$, pine $10-16 \%$, spruce $6-13 \%$, cedar $6-10 \%$, and fir 11-19\% [44]. With age, the relative volume of the crust decreases, and its thickness decreases in the direction from the rump to the top. Deterioration of growing conditions (excessive moisture or desiccation of soil, reduced light supply, etc.) leads to a decrease in the thickness of the crust [45-47]. The choice of processing methods is determined by the origin and amount of bark, its moisture content, composition, shape, and size of bark particles, as well as its storage and transportation conditions [48].

Table 1 provides the chemical composition of softwood bark [49-53].

Table 1. Siberian softwood bark chemical composition [49-53].

\begin{tabular}{|c|c|c|c|c|}
\hline \multirow{2}{*}{ Components } & \multicolumn{4}{|c|}{ Content, $\%$ a.d.m. * } \\
\hline & Picea obovata Ledeb & Larix sibirica Ledeb & Pinus sylvestris L. & Pinus sibirica Du Tour \\
\hline Total ash & 3.47 & 2.42 & 3.17 & 2.68 \\
\hline Extracted by hot water & 4.58 & 11.80 & 6.30 & 4.92 \\
\hline Extracted by ethyl alcohol & 2.54 & 8.30 & 5.25 & 7.13 \\
\hline Total extracted & 7.22 & 20.10 & 11.55 & 12.06 \\
\hline Cellulose & 26.40 & 22.90 & 27.30 & 25.00 \\
\hline König lignin & 27.52 & 21.20 & 23.01 & 21.50 \\
\hline Easily hydrolyzable polysaccharides. & 22.50 & 19.80 & 15.02 & 16.89 \\
\hline Hardly hydrolyzable polysaccharides & 27.80 & 25.30 & 28.82 & 26.18 \\
\hline
\end{tabular}

* Absolute dry raw matter.

The results presented in Table 1 indicate that the chemical composition of larch bark differs markedly from other softwood bark. First of all, this refers to the content of water-extractable substances (as well as suberin and phenolic acids). The content of these components in larch bark is 1.5-3.0 times higher than in other types of softwood. At the 
same time, it has a low content of easily hydrolyzable polysaccharides, 1.5-2.0 times lower than others.

Spruce bark differs from other softwood bark in its low content of extractive substances and, accordingly, in its higher content of easily hydrolyzable polysaccharides. The content of the latter in spruce bark is 1.5-2.0 times higher than in other softwoods. The differences in the content of cellulose and König lignin are less significant.

The cellulose content varies from $22.9 \%$ (larch) to $27.3 \%$ (pine). Spruce bark contains more König lignin, since its content reaches $27.5 \%$, which is $4-6 \%$ more than in other softwoods. The larch bark differs because it not only contains less easily hydrolyzable polysaccharides, but also less König lignin and cellulose.

The data on the mineral components [54] indicate that the main cations in bark ash are calcium $(0.6-0.8 \%)$, sodium $(0.4-0.5 \%)$, and potassium $(0.15-0.27 \%)$, which account for up to $60 \%$ of the total mineral substances. The content of other macroelements (magnesium $(0.1-0.4 \%)$, iron $(0.01-0.02 \%))$ is low. Bark also contains so-called microelements: boron (up to $0.002 \%)$, manganese $(0.02-0.05 \%)$, and copper $(0.001-0.003 \%)$. Moreover, bark contains silicates; stone cells are especially rich in them. The most important anions in bark are phosphates $(0.01-0.06 \%)$.

Thus, bark contains a large number of elements that are necessary for tissue growth, with the exception of nitrogen and sometimes phosphorus.

A review of the softwood bark chemical composition data showed that it differs significantly from timber in terms of the content of its main components and, perhaps most importantly, its high content of extractive substances, and this requires a different approach to choosing how to use and process bark.

The composition of extractive substances of the bark includes compounds of various classes: aliphatic and aromatic hydrocarbons, polyphenols, tannides, fatty acids, sterols, terpenoids, monosaccharides, pectin substances, and a number of other compounds.

The extraction of substances is based on the method of isolating groups of extractive substances with different solubilities in organic solvents and water. In this case, the processing of the crushed bark is carried out with solvents in ascending order of their polarity.

The content of the main components in the bark of various types of larch is shown in Table 2.

Table 2. Group composition of larch bark of various types, \% a.d.m. [55].

\begin{tabular}{cccc}
\hline Components & \multicolumn{3}{c}{ Larch Bark } \\
\cline { 2 - 4 } & $\begin{array}{c}\text { Larix sibirica } \\
\text { Ledeb }\end{array}$ & $\begin{array}{c}\text { Larix gmelinii } \\
\text { (Rupr.) Kuzen. }\end{array}$ & $\begin{array}{c}\text { Larix } \text { kurilensis } \\
\text { Mayr }\end{array}$ \\
\hline Substances, extracted by: & & & \\
Hot water & 11.80 & 18.73 & 21.50 \\
Ethyl alcohol & 8.30 & - & - \\
Alcohol-benzene & 3.90 & 11.40 & 10.90 \\
Cellulose & 22.90 & 19.40 & - \\
Hexosans & 6.10 & - & - \\
Uronic acids & 7.60 & - & 3.72 \\
Pentosans (excluding & 4.50 & 4.36 & 37.40 \\
uronic acids) & 41.66 & 36.12 & 10.50 \\
Klason lignin & 7.60 & 9.60 & - \\
Easily hydrolyzable & & & 2.50 \\
polysaccharides & 23.72 & - & 1.60 \\
Hardly hydrolyzable & 2.42 & 2.80 & \\
polysaccharides & 5.35 & 1.42 & \\
Ash substances & & & \\
Methoxyl groups & &
\end{tabular}

The results of Table 2 indicate that the content of the main components is different in the bark of various types of larch. Siberian larch contains more cellulose and Klason 
lignin and less extractive substances. It also differs significantly in the content of methoxyl groups [55].

The chemical composition of the main components of bark, bast, and cortex is varied. The thickness and quantitative ratio of the layers is different and depends on the age of a tree and the location of the bark along the trunk height. The physical properties of the layers are also very different. The outer cortical layer has 10 times less moisture than the bast layer. Tree bark is much richer in minerals than timber. It has been found that the ash contains macro- and microelements ( $\mathrm{Al}(48-82 \%), \mathrm{Mn}(25-43 \%), \mathrm{Mo}(39-58 \%), \mathrm{Ca}(40-63 \%)$, $\mathrm{P}(17-46 \%), \mathrm{Mg}(24-44 \%), \mathrm{Zn}(35-49 \%), \mathrm{Cu}(13-26 \%), \mathrm{Fe}(28-57 \%), \mathrm{B}(21-57 \%), \mathrm{N}(14-29 \%)$, $\mathrm{K}(25-39 \%), \mathrm{Ni}$ (less than $1 \%$ ), $\mathrm{Cr}$ (less than $1 \%$ ), $\mathrm{Pb}$ (less than 1\%), Si (less than 1\%), and $\mathrm{Na}(25-39 \%))$ [56-59]. Xylose (2.8-3.2\%), arabinose (1.5-1.9\%), and galactose (0.6-1.2\%) are the main monosaccharides in bark that form hemicellulose.

Thus, the bark of the lower part of the trunk has a higher content of inorganic elements and carbon. The bark of lower part is characterized by increased content of ester-soluble substances (lipids), which is obviously associated with the accumulation of hoarding substances (acylglycerols) in old tissues. The content of water-soluble substances, including tannins and carbohydrates, decreases along the height of the trunk in the bast and increases in the bark. A similar picture is observed for alkali-soluble substances containing hemicelluloses and polyflavonoids. At the same time, an increased content of lignin in young bark tissues and cellulose in bark has been observed [60].

\section{Extraction Processing of Coniferous Bark}

Various types of extraction are used to recover components from plant raw materials by means of different extracting agents. Both polar and non-polar solvents can be used. The selection of the extracting agent depends on the nature of the extracted substance. The force field and hydrodynamic conditions have a significant effect on the intensity of the plant raw material extraction. The bark crushing process at the preparation stage for processing is quite important and by itself can determine the way in which this raw material will be used further. Grinding methods have a significant impact on the number of destroyed cells and the efficiency of the extraction process [61-63].

The use of different extracting agents allows biologically active complexes of polyphenolic compounds to be obtained from the bark; the complexes of polyphenolic compounds feature a quantitative predominance of certain fractions, as well as different physiological activities [64]. For example, in the methanol extract of larch bark, the dominant fraction is the oligomeric and polymer fraction of flavonoids. The oligomeric fraction consists of procyanidin and propelargonidin modules. Pyro-type biflavonoids are present in oligomeric and polymeric flavonoid compounds as structural links. Thus, oligomeric and polymeric flavonoids are the product of the condensation of flavan-3-ols [(-)-epiafzelechin, (+)-catechin, (-)-epicatechin] and spiro-type dimmers. Oligomeric and polymeric proanthocyanidins have a positive effect on the cardiovascular system (vasorelaxant activity) and are able to enhance capillary blood circulation (microcirculation), increasing capillary permeability, and have a high antiradical activity [65]. The results of studies carried out by a group of authors [66] showed that the studied softwood types contain a variety of biologically valuable compounds that have good potential for use in the pharmaceutical industry, as well as in agriculture and forestry. The yield of extractives recovered from softwood bark with ethyl acetate is shown in Table 3. 
Table 3. Yield of softwood bark extractive substances, \% a.d.m. [66].

\begin{tabular}{ccccc}
\hline Type of Softwood & $\begin{array}{c}\text { Ethyl Acetate } \\
\text { Extraction } \\
\text { Yield (I) }\end{array}$ & $\begin{array}{c}\text { Hexanoic } \\
\text { Extraction } \\
\text { Yield (II) }\end{array}$ & $\begin{array}{c}\text { Phenolic } \\
\text { Compound } \\
\text { Yield of } \\
\text { Extraction I }\end{array}$ & $\begin{array}{c}\text { Water Extract } \\
\text { Yield (III) }\end{array}$ \\
\hline Larix sibirica Ledeb & 8.65 & 0.69 & 92.0 & 4.75 \\
Abies sibirica Ledeb & 15.17 & 0.34 & 97.8 & 10.0 \\
Pinus sibirica Du Tour & 8.47 & 0.83 & 90.2 & 4.71 \\
Pinus sylvestris L. & 3.67 & 1.19 & 83.7 & 3.82 \\
Picea obovata Ledeb & 3.37 & 1.94 & 42.4 & 6.94 \\
\hline
\end{tabular}

The table shows that fir, larch, and cedar bark is the richest in phenolic compounds. Larch bark is represented by almost all classes of flavonoids, from the flavanone naringenin to bioflavonoids, proanthocyanidins, and condensed tannins. The phenolic complex of larch bark is represented by phenolic acids and their esters; it contains monomeric flavonoids, spiroflavonoids, and oligomeric and polymeric flavonoid compounds.

Larch extracts have p-hydroxybenzoic, vinyl, cis-, trans-p-coumaric, cis-, trans-ferulic, protocatechuic, and caffeic acids, as well as trans-ferulates and trans-coumarates of higher aliphatic alcohols, mainly n-eicosanol $[67,68]$. Stilbenes found in bark are represented by resveratrol and astringenin, and stilbene glycosides are represented by piceid and trans-astringenin-3'-O- $\beta$-D-glucopyranoside [69]. A wide range of compounds is represented by a group of flavonoids: naringenin, eriodictyol, dihydrokaempferol, dihydroquercetin, kaempferol, quercetin, quercetin-3-O-arabinoside, quercetin-3-O-rhamnoside, (-)-epiafzelechin, (+)-catechin, (-)-epicatechin, larixinol, oligoflavonoids (procyanidins), and polymeric flavonoids (condensed tannins). For the first time, flavonoid compounds of the spiro type have been identified: spirobiflavonoids of larixidinol and larizinol, trimertriflarixinol. Spirobiflavonoids are also involved in the formation of oligomeric and polymeric flavonoid compounds (condensed tannins) along with monomeric flavan-3-ols [70].

According to previous studies, it has been established that Siberian larch bark is a great source of unique biologically active phenolic compounds, the quantitative content of which can reach up to $8-12 \%$ of absolute dry matter. The phytocomplex extracted from larch bark shows an antioxidant activity 1.5 times higher than dihydroquercetin [71]. Toxicopharmacological evaluation has shown that the antioxidant complex extracted from larch bark with ethyl acetate has a pronounced capillary-strengthening effect, which surpasses that of dihydroquercetin.

Twenty phenolic compounds have been identified in the ethyl acetate extracts of Siberian larch bast (Larix sibirica Ledeb.) and Gmelin larch bast (Larix gmelinii (Rupr.) Rupr.), which are represented by phenolic acids, flavonoids, and stilbenes. The predominant compounds in the bast of the studied species are compounds with a pyrocatechol type of aromatic ring substitution: trans-astringenin and its $3^{\prime}-O-\beta$-D-glucopyranoside, $+(-)$ catechin, quercetin, and its glycosides, and in the outer cortex (rhytidome), the greatest number of compounds have a p-hydroxyphenyl type of aromatic ring substitution. For the first time, quercetin-3-O- $\alpha$-L-rhamnopyranoside has been found in larch bark. Stilbenes, the presence of which has been established in the bast, have not been found in the rhytidome, however, spirobiflavonoids are absent in the bast [72].

Studies of the quantitative and qualitative composition of phenolic compounds in Siberian spruce bark [73] have revealed that the main monomers and phenolic extractives of the bark are flavonoid dihydroquercetin, stilbene glycosides (isorapontin and astringin), and oligomeric and polymeric phenolic compounds. Flavonoid compounds from the mass of deresined ethyl acetate extract of spruce bark account for 17-18\%, the content of stilbenes and stilbene glycosides accounts for up to $28-30 \%$, and oligomeric and polymeric phenolic compounds account for about $15 \%$. Oligomeric phenolic compounds of Siberian spruce bark consist of building blocks of stilbene glycosides, mainly represented by isorapontin and astringin. Phenolic extract is biologically active and has antioxidant, anti-inflammatory, antitumoral, and cardio- and neuroprotective properties. 
Extractive substances of Siberian silver fir bark are represented by compounds of phenolic class. Aqueous extract of silver fir bark has higher biocidal activity against opportunistic and saprotrophic bacteria. The extract mainly contains quercetin, dihydroquercetin, and kaempferol compounds [74-76].

The presence of phenolic acids, as well as flavonoids (kaempferol, quercetin, dihydroquercetin) is characteristic of pine bark. The monomeric phenolic complex of the water-alkaline extract is mainly represented by phenolic acids.

The following phenolic acids were identified: n-oxybenzoic, n-coumaric, caffeic (3,4dioxicoric), vanillic, ferulic, and simply catechic (3,4-dioxybenzoic) acid. P-coumaric and ferulic acids are represented by cis-and trans-isomers. The oligomers are mainly represented by condensed tannides [77-79].

The following compounds have been identified in the bast: phenolic acids, lignans, stilbene glycosides (resveratroloside and pinostilbenoside), flavonoids (dihydroquercetin, catechin, and kaempferol glycosides), as well as dimeric and trimeric flavonoids (proanthocyanidins consisting of catechin and epicatechin structural models).

Pinosylvin, pinosylvin manomethyl ether, pinosylvin dimethyl ether, resveratrol, pinostilbene, resveratrol trimethyl ether, and stilbene glycosides such as resveratroloside and pinostilbenoside have been found in cedar bark. These compounds are dominant among the phenolic extractives of bark. Phenolic acids, flavonoids (kaempferol, quercetin, and dihydroquercetin) are present in Siberian and Scots pine (Pinus sylvestris L.) bark. The biological activity of stilbenes has shown that pinostilbene, resveratrol, and astringenin display bacteriostatic, fungistatic, and tuberculostatic activity. Pinostilbene is highly active against human tubercle bacillus [80].

Among the phenolic compounds extracted from bark, the substances of tannin nature, which are used as tanning agents in leather production, are of the greatest interest. Tannins are complex polyatomic phenols; their molecule size and hydroxylation degree give them the ability to adequately dissolve in water and easily oxidize in alkaline solutions [81]. Tannins are usually soluble in alcohols, acetone, dioxane, and ethyl acetate if the solution contains at least a little water. In most cases, they are insoluble in ether, benzene, and similar solvents. They are mainly amorphous substances [82,83].

Despite the fact that synthetic tanning agents are widely used in the leather industry, tannins of natural origin have not lost their value. Leather products have a set of properties that are very difficult to reproduce in synthetic materials [84].

The main task for tanning substance extraction is the correct selection of an extraction agent that maximizes the substance extraction from the raw material.

Tanning substances are almost completely recovered as a result of a water-alkaline extraction. The effect of alkaline solutions causes the hydrolysis of condensed structures. The highest yield of extractives from larch bark is observed when using 1-1.5\% alkali water solution or 15-20\% ethyl alcohol as an extraction agent. When using an alkali water solution, the yield of extractive substances is up to $40 \%$, and the yield is $7-8 \%$ more when using a water-alcohol solution. The maximum yield of extractives from pine bark occurs when using a $2 \%$ sodium hydroxide solution.

Catechol, catechin, dihydroquercetin, quercetin, campherol, dihydromyricetin, and resveratrol have been identified in an alcohol extract of larch bark using a mass spectrometer [85].

The concentration of sodium hydroxide has a significant effect on the extraction efficiency, the results of studies indicate that when using a 1.5\% $\mathrm{NaOH}$ solution, 2.5 times more substances are extracted than when using a $0.1 \%$ solution. This is due to the fact that structural changes of water under the influence of electrolytes, in particular $\mathrm{NaOH}$, are significant only at moderate concentrations (from 0.2 to $2-3 \mathrm{~mol} / \mathrm{L}$ ). Among the available alkali metal hydroxides, $\mathrm{NaOH}$ is more effective, since it is better able to penetrate the capillary-porous structure of a substance [86].

Scientists of the Wood Chemical Engineering and Biotechnology Department, Reshetnev Siberian State University of Science and Technology, Krasnoyarsk, Russia, have con- 
ducted research on the effect of extraction duration on the composition of water-alkaline extracts of Siberian larch. The bark has been preliminarily crushed to particles ranging from 0.5 to $1 \mathrm{~mm}$ in size; the extraction has been carried out with a $1 \%$ sodium hydroxide solution, the process temperature was $90^{\circ} \mathrm{C}$, the liquid module was $1 / 9$, and the extraction duration was $35 \mathrm{~min}$. According to the studies, the authors have established that the duration of a water-alkaline extraction process significantly affects the quality of the obtained extract, while the most complete extraction of tannins occurs from the raw material, and the processes of hydrolysis and condensation of tannins do not have a big effect on the quality of the extract obtained. The yield of a larch extract is at minimum $55 \%$, and the purity is $43 \%$ [87-90].

One of the extraction methods is to use an organic ampholyte solvent as an additive to the main extraction agent-water. Monoethanolamine (MEA) has been chosen as an additive to water due to the following reasons. Firstly, MEA is a typical ampholyte and, therefore, its presence in the extraction agent facilitates transition to the liquid phase of substances of a different nature. Secondly, being an antioxidant and a weak destructive agent for lignin [91], MEA is able to prevent oxidative processes, as well as to inhibit the condensation of polyphenolic compounds and ensure the preservation of the carbohydrate complex [92]. Thirdly, when using MEA, the rate and completeness of extractive substance recovery may be increased, since this solvent is a good swelling agent for plant raw materials [93]. Apart from monoethanolamine, other ampholytes also have the same properties [94].

The use of monoethanolamine as an additive to the main extraction agent (water) in the amount of $1.0 \%$ to $5.0 \%$ allows for the extraction of $28 \%$ to $58 \%$ of low molecular weight substances from softwood bark, including a certain amount of easy-to-hydrolyze polysaccharides (6.8-19.0\% of extract dry matter mass), while with other ways of extractive substance recovery, the maximum yield has been about $24 \%$ with $12.3 \%$ of total concentration of organic solvents in the extraction agent [95].

The use of monoethanolamine as an additive to the main extraction agent makes it possible to extract from softwood bark, for example, larch bark, up to $50 \%$ of phenolic substances, which makes the obtained extracts promising for further processing [96].

Extraction products obtained using monoethanolamine have antimicrobial properties, in some cases with prolonged action, which are provided by phenolic compounds [97].

There is a method of obtaining tanning extracts with a preliminary short-term bark activation, followed by extraction using a water-alcohol solution [98]. This method allows the yield of tannins to be increased.

The presence of a significant amount of substances that do not have the tanning effect in softwood bark extracts reduces the extract quality and limits their use. This is especially applicable to alkaline extracts from softwood timber barking residues, in which the content of tanning substances is less than $40 \%$. Tanning extracts are refined in order to improve the quality of the obtained plant extracts. The most effective methods for refining alkaline extracts are neutralization with an ion exchange resin, sulfitation, and ultrafiltration.

The extract study results have revealed that non-tannins have a molecular mass 400-1000 less than that of tannins (i.e., the difference in the molecular mass between them is very significant), and this, in turn, makes it possible to refine extracts by means of ultrafiltration. This method allows extracts to be obtained with a defined level of quality regardless of the bark composition at the stage of tanning extract refinement and, thereby, helps solve the problem of wood waste recycling. Ultrafiltration is a delicate hydromechanical process. The main driving force behind the process is a pressure difference on both sides of the membrane.

Depending on the purpose of the process, semi-permeable membranes with pore sizes from $5 \times 10^{-9}$ to $5 \times 10^{-8} \mathrm{~m}$ and porosity of $\approx 80 \%$ are used for ultrafiltration. Ultrafiltration separation of mixtures is carried out using four main types of membranes: the asymmetric Loeb-Sourirajan membranes, composite membranes, nuclear filters, and hollow fibers. Semi-permeable membranes in the form of hollow fibers have an asymmetric 
structure. The main advantage of hollow fibers is a larger surface area of the membranes per unit volume of the appliance. The high packing density of fibers in the membrane module ensures the high performance of hollow fiber appliances.

During the ultrafiltration of tanning solutions, they are concentrated and purified from mineral salts and other low molecular weight impurities, which pass into the permeate (filtrate). At the same time, high-molecular tannins remain in the concentrate (the solution above the membrane), and the solution purity increases significantly. The optimum conditions for this ultrafiltration process are as follows: pressure of $400 \mathrm{kPa}$, temperature of the fractionated spent tanning solution of $35^{\circ} \mathrm{C}$ max., and $\mathrm{pH}$ value of 4-5 [99-101]. An increase in temperature above $35^{\circ} \mathrm{C}$ causes the disaggregation of colloidal particles and increases their mobility. In this case, the ratio of solution components changes towards highly dispersed components, which contributes to the penetration of tannins into the filtrate, and the concentrate purity decreases. A decrease in the acidity of the fractionated tanning solution from $\mathrm{pH} 4$ to $\mathrm{pH} 6$, just like an increase in temperature, disaggregates the colloidal associates of tannins, which negatively affects the selectivity and productivity of the ultrafiltration process.

The results of Table 4 show that the highest yield of tannides is observed using a hollow fiber ultrafiltration acetate cellulose membrane with a pore size of 10 micrometers (UMAC-HF10*).

Table 4. Influence of membrane type on the tannin yield of aqueous-alkaline extract of Larix sibirica Ledeb bark, \% a.d.m. [89].

\begin{tabular}{|c|c|c|c|c|c|c|c|}
\hline \multirow{2}{*}{$\begin{array}{c}\text { Name of the } \\
\text { Fraction }\end{array}$} & \multicolumn{7}{|c|}{ Content of Substances, \% a.d.m. } \\
\hline & HMAC-50 ${ }^{a}$ & HМAC-80 & UMAC-HF10 $^{\text {b }}$ & UMAC-HF10 * & UMAC-50 c & UMAC-100 & UMAC-500 \\
\hline Concentrate & 96.2 & 97.1 & 95.3 & 95.8 & 93.6 & 96.3 & 96.3 \\
\hline Filtrate & 1.4 & 0.3 & 0.3 & 0.7 & 3.6 & 1.0 & 3.7 \\
\hline $\begin{array}{l}\text { Precipitate on the } \\
\text { membrane }\end{array}$ & 2.4 & 2.6 & 4.4 & 3.5 & 2.8 & 2.7 & - \\
\hline $\begin{array}{c}\text { Tannin yield } \\
\text { (concentrate + } \\
\text { filtrate) }\end{array}$ & $\frac{43.9}{81.2}$ & $\frac{34.7}{74.7}$ & $\frac{82.4}{187.9}$ & $\frac{74.8}{170.6}$ & $\frac{74.3}{156.8}$ & $\frac{48.2}{112.9}$ & $\frac{34.4}{76.1}$ \\
\hline
\end{tabular}

${ }^{a}$ Hyperfiltration membrane acetate cellulose. ${ }^{b}$ Ultrafiltration membrane acetate cellulose-hollow fiber. ${ }^{\mathrm{c}}$ Ultrafiltration membrane acetate cellulose. * - the volume of the selected filtrate was $25 \%$.

Another promising raw material for obtaining tanning substances is pine bark. Studies of the bark chemical composition [102-105] indicate that it is a valuable raw material for chemical processing.

The results given in Table 5 show that pine bark is a complex of substances, consisting of extractives, polysaccharides, and lignin. Extractive substances are of the greatest interest. The maximum recovery of extractives is achieved with $2 \% \mathrm{NaOH}$. The yield of substances extracted with alkali is 6 times more than water-soluble substances and 1.5 times more than alcohol-soluble substances; after a neutralization on a cation exchange resin KU-2, pine bark already has a high purity reaching more than $60 \%$. The research results are given in Table 6.

Table 5. Chemical composition of the bark of Pinus sylvestris L. [106].

\begin{tabular}{cc}
\hline Components & Content, \% a.d.m. \\
\hline Total ash & $3.2 \pm 1.3$ \\
Substances extracted by hot water & $7.2 \pm 2.4$ \\
Substances extracted with $\%$ sodium hydroxide & $44.0 \pm 4.1$ \\
Substances extracted by ethyl alcohol & $31.6 \pm 4.5$ \\
Easily hydrolyzable polysaccharides & $13.4 \pm 3.2$ \\
Hardly hydrolyzable polysaccharides & $27.8 \pm 4.4$ \\
Lignin substances & $43.0 \pm 3.7$ \\
\hline
\end{tabular}


Table 6. Purification extract bark of Pinus sylvestris L. [106].

\begin{tabular}{cl}
\hline Extract Refining Stages & Purity, \% \\
\hline Neutralization with a cation exchange resin KU-2 & $68.4 \pm 3.0$ \\
Treatment with sodium sulfite & $70.6 \pm 3.2$ \\
Ultrafiltration, concentration 25\% & $65.2 \pm 5.0$ \\
\hline
\end{tabular}

Thus, a water-alkaline extract of pine bark does not require additional refinement by ultrafiltration; it is sufficient only to neutralize the extract on the KU-2 resin and modify it by sulfitation [106].

The water-alkaline extract is mostly represented by polyphenolic compounds, a significant part of which has tanning properties, according to the results of tannin determination as per the All-Union Standard Method (VEM, 1953).

Since the production of hide powder, a sorbent used in the VEM method, has been currently stopped, the method has been modified, and collagen is used as a sorbent substance, which is very similar in structure to hide powder [107]. The research results given in Table 7 show that the extract composition is represented by more than $60 \%$ by substances of tannin nature, the purity of this extract is at minimum $61 \%$.

Table 7. Composition of aqueous-alkaline extract bark of Pinus sylvestris L. [107].

\begin{tabular}{ccc}
\hline \multirow{2}{*}{ Component } & \multicolumn{2}{c}{ Content } \\
\cline { 2 - 3 } & VEM Collagen Method & VEM Hide Powder Method \\
\hline Dry substances, g/L & & 23.5 \\
Insoluble substances, \% & 1.3 & 2.1 \\
Soluble substances, \% & 98.7 & 97.9 \\
Non-tannins, \% & 36.7 & 40.0 \\
Tannins, \%; & 63.3 & 60.0 \\
Purity, \% & 64.1 & 61.3 \\
\hline
\end{tabular}

\section{Use of the Post-Extraction Residue}

A result of the production of high-purity tanning extracts from softwood bark is a large-tonnage solid residue, the so-called tan, which has not found widespread use at present.

The chemical composition of the larch bark tan is given in Table 8 [108,109].

Table 8. Chemical composition of tan bark Larix sibirica Ledeb, \% a.d.m. [108,109].

\begin{tabular}{cc}
\hline Components & Content, \% a.d.m. \\
\hline Substances extracted by hot water & 4.2 \\
Easy-to-hydrolyze polysaccharides & 15.3 \\
Hard-to-hydrolyze polysaccharides & 41.0 \\
Cellulose & 37.0 \\
Lignin substances & 46.1 \\
Total ash & 1.5 \\
\hline
\end{tabular}

The results of Table 8 show that the larch bark tan is represented mainly by polysaccharides and lignin. The share of polysaccharides accounts for up to $50 \%$, the main portion of which is hard-to-hydrolyze polysaccharides. The polysaccharide content in the tan is higher than in the bark. Thus, the lignin content requires delignification in order to obtain a high-quality cellulose semi-product.

Thus, given the relatively high polysaccharide content, tan can be classified as a potential raw material for the production of cellulosic materials.

One of the ways to carry out delignification is oxidative destruction [109]. The main factors which have an impact on obtaining a product are the flow rate and concentration of hydrogen peroxide, the temperature and duration of processing, and the $\mathrm{pH}$ of the medium. The optimum parameters for the delignification of the larch bark tan are the 
following: temperature $80{ }^{\circ} \mathrm{C}$, duration $2 \mathrm{~h}$, hydrogen peroxide concentration $6 \%$, and liquid module 10 . The cellulose yield is up to $35 \%$ and the lignin content is $46 \%$; thus, one treatment with hydrogen peroxide is not sufficient for a high-degree delignification. In this case, it becomes necessary to carry out a multi-stage delignification; one of the methods is bioconversion, in particular, by Trichoderma fungi. As a result of the conversion, lignin decreases to $21.4 \%$, and cellulose enrichment is up to $48.2 \%$. Application of the combined impact on the lignin-carbohydrate complex of the larch bark tan leads to an increase in cellulose; this is accompanied by lignin destruction. The resulting semi-product has a highly developed porous structure; this product is similar in its characteristics to powdered cellulose and can be used as a carrier for various biologically active substances [109].

In addition to oxidative destruction, tan can become a promising raw material for organosolv pulping in the acetic acid-hydrogen peroxide-water media, which has a number of advantages over traditional methods of cellulose pulping: toxic sulfur-containing compounds are excluded from the production cycle of cellulose pulping; the delignification process is carried out under mild conditions to obtain high-quality cellulose; the possibility of relatively low investment capital and ensuring the profitability of small and medium-sized enterprises [110].

The use of peroxy acid contributes to the production of bleached cellulose, which does not require additional processing. The spent pulping liquor can be reused (recycled) by adding fresh reagents and bringing them to a predetermined concentration [111]. The non-traditional pulping is an environmentally friendly method that does not require high temperature and pressure.

An alternative option is biotechnological processing - the transformation of some organic compounds of biological raw materials into others under the influence of enzymatic systems of microbial origin.

Various methods of bioconversion are used to regulate the phytopathogen population number and to obtain antimicrobial drugs; the dominant position is occupied by Trichoderma microscopic fungi which have a high antagonistic and superparasitic activity. It is known that Trichoderma fungi are able to actively participate in the destruction of lignin-cellulose waste from wood industry enterprises. The peculiarity of the fungus to decompose lignin substances along with cellulosic substances puts it in a number of agents capable of transforming plant raw materials of wood origin and allows for the potential to use this ability in the future to create a wood waste processing technology and to obtain bioproducts with a protective effect. The fungus' cellulolytic enzymes cannot penetrate the cellulose fibrils; they act only on the surface. The number of glycosidic bonds receptive to the effects of the enzymes depends on the cellulose's swelling degree. The increase in reactivity of cellulose depends on the grinding degree and the pretreatment of the raw material. The exposure to the effect of the enzyme complex is affected by the presence of inhibitors in the substrate, in particular, substances of phenolic origin [112].

Tan obtained as a result of larch bark treatment with alkali can be used as a substrate to obtain a biological product of the trichodermin type based on the strain MG-97 T. asperellum [113].

Larch bark extracts can be used as a modifying agent to obtain urea foam plastics [114] to improve strength characteristics.

\section{Conclusions}

Wood waste is a potentially important source of raw materials. Waste is generated as a by-product during the harvesting and processing of wood around the world. Therefore, the use of bark is of exceptional importance because of its unique chemical components and unusual structure.

The conducted search and study of literary sources has included a general overview of the chemical composition of bark and bark processing. Special attention was drawn to extractive substances of the bark, among which phenolic compounds with biological 
activity and tanning ability are important. Although synthetic tanning agents are widely used in the leather industry, tannides of natural origin have not lost their significance.

In the tanning and extract industry, the extracts obtained have a low yield and good quality, which generates interest in further studying this problem.

In the production of tanning extracts, a multi-tonnage waste is a post-extraction residue, the so-called tan, which has not yet found a qualified application.

The review has covered the ways of tree bark processing that allow its products to be used in various industries.

Author Contributions: V.S.F.: writing-review and editing; T.V.R.: supervised the project and assisted in writing the review. All authors have read and agreed to the published version of the manuscript.

Funding: The research was conducted under the governmental task issued by the Ministry of Education and Science of Russia for the "Technology and Equipment for the Chemical Processing of the Plant Biomass Material" project by the Plant Material Deep Conversion Laboratory (topic number FEFE-2020-0016).

Conflicts of Interest: The authors declare no conflict of interest. The funders had no role in the design of the study; interpretation of data; in the writing of the manuscript and in the decision to publish the results.

\section{References}

1. Food and Agriculture Organization (FAO). Global Forest Resources Assessment 2020-Key Findings; FAO: Rome, Italy, 2020. Available online: http:/ /www.fao.org/documents/card/en/c/ca8753en (accessed on 25 May 2021).

2. Decree of the Governor of the Krasnoyarsk Territory No. 332-ug Dated 21 December 2018 "On the Approval of the Forest Plan of the Krasnoyarsk Territory" Introd. 01 January 2019. Krasnoyarsk. 2018, p. 73. Available online: http://docs.cntd.ru/document/ 550303431 (accessed on 25 May 2021). (In Russian).

3. Morozov, V.I.; Petrusheva, N.A. The Use of Potential Wood Greenery Resources of Coniferous Forests of the Krasnoyarsk Territory. Tendentsii Razvit. Nauk. I Obraz. [Trends Dev. Sci. Educ.] 2019, 50, 38-41. (In Russian)

4. Bryukhanov, A.V. Ecological assessment of the state of forests in Siberia: Alarming results. Ustoychivoye Lesopol'zovaniye [Sustain. For. Manag.] 2009, 2, 21-31. (In Russian)

5. Gubanenko, G.A.; Rechkina, E.A. Influence of pectin of wood greens of scots pine on the quality of wheat flour gluten. In Proceedings of the International Scientific and Practical Conference Technologies of Food Production and Examination of Goods, Kursk, Russia, 2-3 April 2015; pp. 58-60. (In Russian).

6. Chistova, N.G.; Mironov, G.S. The Integrated Use of Wood; SibGTU: Krasnoyarsk, Russia, 2011; p. 226, ISBN 978-5-8173-0503-6.

7. Simonov, M.N.; Yugov, V.G. Debarking of Wood; Forest industry: Moscow, Russia, 1972; p. 127.

8. Ushanova, V.M. The Processing of Siberian Fir Wood Greenery and Bark with the Production of Biologically Active Products. Khvoinye Borealnoi Zony [Conifers Boreal Zone] 2013, 31, 138-142. (In Russian)

9. Forest Plan of the Krasnoyarsk Territory, Krasnoyarsk, Russia. 2009, p. 210. Available online: http://docs.cntd.ru/document/42 2436834 (accessed on 15 May 2021). (In Russian).

10. Ryazanova, T.V.; Loskutov, S.R.; Aniskina, A.A. The Effect of Storage of Wood Green of Fir to the Composition of the Essential oil. In Proceedings of the International Conference on Scientific Research of the SCO Countries: Synergy and Integration, Part 1: Participants' Reports in English, Beijing, China, 25-26 March 2019; pp. 163-168. Available online: https://kpfu.ru/staff_files/F_ 1183896347/Scientific_research_of_the_SCO_countries_EEnglish_Reports__March_25_26__Part_1_2_.pdf (accessed on 15 May 2021).

11. Mamaeva, O.O.; Isaeva, E.V. Use of Post-Extraction Fir Wood Greenery Residues by the Bioconversion Method with the Production of Feed Additives. Forests 2021, 12, 272. [CrossRef]

12. Schafer, J.L.; Breslow, B.P.; Hohmann, M.G.; Hoffmann, W.A. Relative Bark Thickness is Correlated with Tree Species Distributions Along a Fire Frequency Gradient. Fire Ecol. 2015, 11, 74-87. [CrossRef]

13. Catry, F.X.; Rego, F.; Moreira, F.; Fernandes, P.M.; Pausas, J.G. Post-fire tree mortality in mixed forests of central Portugal. For. Ecol. Manag. 2010, 260, 1184-1192. [CrossRef]

14. Wang, G.G.; Wangen, S.R. Does frequent burning affect longleaf pine (Pinus palustris) bark thickness? Can. J. For. Res. 2011, 41, 1562-1565. [CrossRef]

15. Johnson, E.A.; Miyanishi, K. Forest Fires: Behavior and Ecological Effects; Academic Press: New York, NY, USA, 2001; p. 585, ISBN 0-12-386660-x.

16. Fekete, Z. Erdőbecsléstan; Akadémiai Kiadó: Budapest, Hungary, 1951; p. 628. 
17. Härtel, O. Pollutants accumulation by bark. In Monitoring of Air Pollutants by Plants-Methods and Problems, Proceedings of the International Workshop, Osnabrück, Germany, 24-25 September 1981; Steubing, L., Jäger, H.-J., Eds.; W. Junk Publishers: The Hague, The Netherlands, 1982; pp. 137-147, ISBN 978-90-6193-947-4.

18. Kuik, P.; Wolterbeek, H.T. Factor analysis of trace-element data from tree-bark samples in the Netherlands. Environ. Monit. Assess. 1994, 32, 207-226. [CrossRef] [PubMed]

19. Böhm, P.; Wolterbeek, H.; Verburg, T.; Musílek, L. The use of tree bark for environmental pollution monitoring in the Czech Republic. Environ. Pollut. 1998, 102, 243-250. [CrossRef]

20. Saarela, K.E.; Harju, L.; Rajander, J.; Lill, J.O.; Heselius, S.J.; Lindroos, A.; Mattsson, K. Elemental analyses of pine bark and wood in an environmental study. Sci. Total. Environ. 2005, 343, 231-241. [CrossRef]

21. Mandiwana, K.L.; Resane, T.; Panichev, N.; Ngobeni, P. The application of tree bark as bio-indicator for the assessment of Cr(VI) in air pollution. J. Hazard. Mater. 2006, 137, 1241-1245. [CrossRef] [PubMed]

22. Ivanova, N.V.; Levchuk, A.A.; Babkin, V.A. Study of the influence of technogenic factors on the content of extractive substances in larch bark. Khimija Rastit. Syr'ja [Chem. Plant Raw Mater.] 2014, 1, 113-117. (In Russian) [CrossRef]

23. Randall, J.M.; Hautala, E.; Waiss, C.A.; Tschernitz, J.L. Modified barks as scavengers for heavy metalions. For. Prod. J. 1976, 26, 46-50.

24. Fan, Y.; Klemeš, J.; Perry, S.; Lee, C. Anaerobic digestion of lignocellulosic waste: Environmental impact and economic assessment. J. Environ. Manag. 2019, 231, 352-363. [CrossRef]

25. Permakov, G.V.; Loskutov, S.R.; Semenovich, A.V. Extraction of bark of coniferous water-organic extractants. Khimija Rastit. Syr'ja [Chem. Plant Raw Mater.] 2008, 2, 43-46. (In Russian)

26. Teplova, V.V.; Isakova, E.P.; Klein, O.I.; Dergachova, D.I.; Gessler, N.N.; Deryabina, Y.I. Natural Polyphenols: Biological Activity, Pharmacological Potential, Metabolic Engineering Paths. Prikl. Biohim. I Mikrobiol. [Appl. Biochem. Microbiol.] 2018, 54, $221-237$. (In Russian) [CrossRef]

27. Faggian, M.; Bernabè, G.; Ferrari, S.; Francescato, S.; Baratto, G.; Castagliuolo, I.; Dall'Acqua, S.; Peron, G. Polyphenol-Rich Larix decidua Bark Extract with Antimicrobial Activity against Respiratory-Tract Pathogens: A Novel Bioactive Ingredient with Potential Pharmaceutical and Nutraceutical Applications. Antibiotics 2021, 10, 789. [CrossRef] [PubMed]

28. Babkin, V.A.; Ostrukhova, L.A.; Kopylova, L.I. Natural products and their derivatives obtained by technology of a closed cycle of biomass processing of the larch of Siberian. Khimija Rastit. Syr'ja [Chem. Plant Raw Mater.] 2016, 1, 121-126. (In Russian) [CrossRef]

29. Ivanov, I.P.; Veprikova, E.V.; Chesnokov, N.V. Effect of conditions of carbon sorbents producing from abies bark ontheir structure and sorption properties. SFU Chem. 2019, 12, 423-433. (In Russian) [CrossRef]

30. Kuznetsova, S.A.; Skvortsova, G.P.; Moroz, A.A.; Schislenko, S.A.; Korolkova, I.V.; Chesnokov, N.V.; Kuznetsov, B.N. Enterosorbents from abies bark and their therapeutic and preventive properties in experimental escherichiosis of animals. SFU Chem. 2020, 13, 122-132. [CrossRef]

31. Lust, J. The Herb Book: The Most Complete Catalog of Herbs Ever Published, Reprint ed.; Dover Publications: New York, NY, USA, 2014; p. 640, ISBN 978-0486781440.

32. Semenovich, A.V.; Loskutov, S.R.; Permakov, G.V. Collecting petroleum products of modified coniferous breed bore. Khimija Rastit. Syr'ja [Chem. plant raw Mater.] 2008, 2, 113-118. (In Russian)

33. Pásztory, Z.; Mohácsiné, I.R.; Gorbacheva, G.; Börcsök, Z. The utilization of tree bark. BioResources 2016, 11, 7859-7888. [CrossRef]

34. Borysiuk, P.; Boruszewski, P.; Auriga, R.; Danecki, L.; Auriga, A.; Nowacka, M.; Rybak, K. Influence of a bark-filler on the properties of PLA biocomposites. Mendeley Data 2021, 1, 9196-9208. [CrossRef]

35. Makarychev, S.V. The thermophysical properties of thermoplastics made on the basis of wood waste. Vestn. Altayskogo Gos. Agrar. Univ. [Bull. Altai State Agrar. Univ.] 2015, 6, 139-142. (In Russian)

36. Gößwald, J.; Barbu, M.-C.; Petutschnigg, A.; Tudor, E.M. Binderless Thermal Insulation Panels Made of Spruce Bark Fibres. Polymers 2021, 13, 1799. [CrossRef] [PubMed]

37. Kain, G.; Tudor, E.M.; Barbu, M.-C. Bark Thermal Insulation Panels: An Explorative Study on the Effects of Bark Species. Polymers 2020, 12, 2140. [CrossRef] [PubMed]

38. Barbu, M.C.; Lohninger, Y.; Hofmann, S.; Kain, G.; Petutschnigg, A.; Tudor, E.M. Larch Bark as a Formaldehyde Scavenger in Thermal Insulation Panels. Polymers 2020, 12, 2632. [CrossRef] [PubMed]

39. Tudor, E.M.; Barbu, M.C.; Petutschnigg, A.; Réh, R.; Krišt'ák, L'. Analysis of Larch-Bark Capacity for Formaldehyde Removal in Wood Adhesives. Int. J. Environ. Res. Public Health 2020, 17, 764. [CrossRef]

40. Tudor, E.M.; Scheriau, C.; Barbu, M.C.; Réh, R.; Krišt'ák, L'; Schnabel, T. Enhanced Resistance to Fire of the Bark-Based Panels Bonded with Clay. Appl. Sci. 2020, 10, 5594. [CrossRef]

41. Anderson, A.B.; Wong, A.; Wu, K.T. Utilization of white fir bark and its extracts in particleboard. For. Prod. J. 1974, $24,40-45$.

42. Anderson, A.B.; Wong, A. Douglas fir and western hemlock bark extracts as bonding agents for particleboard. For. Prod. J. 1975, $25,45-48$.

43. Zribi, W.; Aragües, R.; Medina, E.; Faci, J.M. Efficiency of inorganic and organic mulching materials for soil evaporation control. Soil Tillage Res. 2015, 148, 40-45. [CrossRef]

44. Ponomareva, N.G. Improving the Technology of Production of Fuel Pellets from Wood Bark. Ph.D. Thesis, Northern (Arctic) Federal University named after M. V. Lomonosov, Arkhangelsk, Russia, 2017. (In Russian). 
45. Eremin, V.M. The effect of excessive moisture on the anatomical structure of pine bark ordinary. Izv. Vyss. Uchebnykh Zavedeniy. Lesn. Zhurnal [Proc. High. Educ. Inst. For. J.] 1975, 2, 7-11. (In Russian)

46. Eremin, V.M. On the influence of abiotic environmental factors on the anatomical structure of the cortex. Izv. Vyss. Uchebnykh Zavedeniy. Lesn. Zhurnal [Proc. High. Educ. Inst. For. J.] 1982, 4, 23-27. (In Russian)

47. Khramchenkova, O.M.; Drozdov, D.N.; Novikov, R.I.; Savchenko, A.M. Altitude distribution of ash content and elemental composition of Scots pine (Pinus Sylvestris L.) crust. Vestn. Poles. Gos. Univ. Seriya Prirodoved. Nauk. [Bull. Poles. State Univ. Ser. Nat. Sci.] 2016, 2, 34-38, (In The Republic of Belarus).

48. Ryazanova, T.V.; Repyakh, S.M. Chemistry and Technology of Conifer Bark: Monograph; KGTA: Krasnoyarsk, Russia, 1996; p. 301, ISBN 5-230-17473-0.

49. Obolenskaya, A.V.; Nikitin, V.M.; Shcheglov, V.P. Chemistry of Wood and Cellulose; Forest Industry: Moscow, Russia, 1978; p. 367, ISBN 978-5-458-34022-9.

50. Ryazanova, T.V.; Chupova, N.A.; Isaeva, E.V. Chemistry of Wood; LAP Lambert Academic Publishing GmbH \& Co. KG: Saarbrucken, Germany, 2012; p. 428, ISBN 978-3-8473-7148-9.

51. Barabash, N.D.; Levin, E.D.; Astapkovich, I.N. On the chemical composition of the bark of Larix sibirica. Him. Prir. Soedin. [Chem. Nat. Compd.] 1970, 3, 386-387. (In Russian)

52. Dolgodvorova, S.Y.; Scrinic, L.A.; Chernyaeva, G.N. Wood extractive substances and bark of woody rocks of Siberia. Message 3. Rastit. Resur. [Plant Resour.] 1976, T. XII, 84-88. (In Russian)

53. Ivanova, M.A. Wood Chemistry; Forest Industry: Moscow, Russia, 1982; p. 399.

54. Chuprova, N.A.; Azhar, L.P.; Patrusheva, L.E.; Usova, V.T. Study of the chemical composition of aqueous extracts of larch components of Siberian. Khimiya I Khimicheskaya Tekhnologiya Drev. [Chem. Chem. Technol. Wood] 1975, 3, 99-105. (In Russian)

55. Rubchevskaya, L.P.; Levin, E.D.; Chuprova, N.A. Chemical composition of larch bark in various periods of the annual cycle. In Vsesoyuznaya Conferences Study and Use of Tree Bark; Krasnoyarsk, Russia, 1977; pp. 10-11. (In Russian)

56. Lambert, M.J. Inorganic constituents in wood and bark of New South Wales forest tree species. For. Comm. New South Wales Res. Note 1981, 45, 43.

57. Olander, B.; Steenari, B.M. Characterization of ashes from wood and straw. Biomass Bioenergy 1995, 8, 105-115. [CrossRef]

58. Piotrowska, P.; Skoglund, N.; Grimm, A.; Boman, C.; Öhman, M.; Zevenhoven, M.; Boström, D.; Hupa, M. Systematic studies of ash composition during the co-combustion of rapeseed cake and bark. In Proceedings of the 21st International Conference on Fluidized Bed Combustion, Naples, Italy, 3-6 June 2012; pp. 219-226.

59. Wang, L.; Dibdiakova, J. Characterization of ashes from different wood parts of Norway spruce tree. Chem. Eng. Trans. 2014, 37, 37-42. [CrossRef]

60. Daineko, I.P.; Daineko, I.V.; Belov, L.P. Study of the chemical composition of pine bark. Khimija Rastit. Syr'ja [Chem. Plant Raw Mater.] 2007, 1, 19-24. (In Russian)

61. Ryazanova, T.V. Innovative Technologies in Chemical Wood Processing; SibSTU: Krasnoyarsk, Russia, 2011; p. 160. (In Russian)

62. Ryazanova, T.V.; Chuprova, N.A.; Kim, N.Y. On intensification of the process of extraction of Siberian larch bark in the disintegrator. Khimija Rastit. Syr'ja [Chem. Plant Raw Mater.] 2000, 1, 95-100. (In Russian)

63. Alashkevich, Y.D.; Marchenko, R.A.; Reshetova, N.S. The process of knife-free treatment of fibrous suspension in the "jet-barrier" installation. Khimija Rastit. Syr'ja [Chem. Plant Raw Mater.] 2009, 2, 157-163. (In Russian)

64. Feng, S.; Cheng, S.; Yuan, Z.; Leitch, M.; Xu, C. Valorization of bark for chemicals and materials: A review. Renew. Sustain. Energy Rev. 2013, 26, 560-578. [CrossRef]

65. Gordienko, I.I.; Fedorova, T.E.; Ivanova, S.Z.; Babkin, V.A. The influence of the extractant on the component composition of the phenolic complex extracted from the bark of the hemeline larch. Khimija Rastit. Syr'ja [Chem. Plant Raw Mater.] 2008, 2, 35-38. (In Russian)

66. Ostroukhova, L.A.; Fedorova, T.E.; Onuchina, N.A.; Levchuk, A.A.; Babkin, V.A. Determination of the quantitative content of extractive substances from wood, roots and bark of trees of coniferous species of Siberia: Larch (Larix Sibirica L.), pine (Pinus Sylvestris L.), fir (Abies Sibirica L.), spruce (Picea Obovata L.) and cedar (Pinus Sibirica Du Tour.). Khimija Rastit. Syr'ja [Chem. Plant Raw Mater.] 2018, 4, 185-195. (In Russian) [CrossRef]

67. Ivanova, S.Z.; Fedorova, T.E.; Ivanova, N.V.; Fedorov, S.V.; Ostroukhova, L.A.; Malkov, Y.A.; Babkin, V.A. Flavonoid compounds of the bark of the larch of Siberian and larch of Gmelin. Khimija Rastit. Syr'ja [Chem. Plant Raw Mater.] 2002, 4, 1-15. (In Russian)

68. Ivanova, S.Z.; Gorshkov, A.G.; Kuzmin, A.V.; Gordienko, I.I.; Babkin, V.A. Phenolic compounds of Siberian and Dahurian larch phloem. Russ. J. Bioorganic Chem. 2012, 38, 769-774. (In Russian) [CrossRef]

69. Ivanova, S.Z.; Fedorova, T.E.; Fedorov, S.V.; Babkin, V.A. Stilbena bark larch Gmelin. Khimija Rastit. Syr'ja [Chem. Plant Raw Mater.] 2008, 4, 83-88. (In Russian)

70. Fedorova, T.E.; Ivanova, S.Z.; Babkin, V.A. Spiroflavonoid Compounds: Structure and Distribution in Nature Review. Russian J. Bioorganic Chem. 2010, 36, 793-801. (In Russian) [CrossRef]

71. Babkin, V.A.; Ostroukhova, L.A.; Ivanova, N.V.; Malkov, Y.A.; Ivanova, S.Z.; Onuchina, N.A. Phytocomplex with Antioxidant Activity and Method of Its Production 2002. Russian Federation Patent 2188031, 27 August 2002. (In Russian).

72. Ivanova, S.Z.; Gorshkov, A.G.; Kuzmin, A.V.; Gordienko, I.I.; Babkin, V.A. Phenolic compounds of the luba larch of Siberian and larch of Gmeline. Khimija Rastit. Syr'ja [Chem. Plant Raw Mater.] 2011, 2, 107-112. (In Russian) 
73. Fedorova, T.E.; Fedorov, S.V.; Babkin, V.A. Phenolic compounds of the crust Picea obovata Ledeb. Khimija Rastit. Syr'ja [Chem. Plant Raw Mater.] 2018, 1, 89-95. (In Russian) [CrossRef]

74. Gromova, A.S.; Lutsky, V.I.; Tyukavkina, N.A. Fenolokislots luba Abies nephrolepis, Pinus sibirica and P. sylvestris. Khimiya Prir. Soyedineniy [Chem. Nat. Compd.] 1977, 2, 227. (In Russian)

75. Gromova, A.S. Phenolic Compounds of the Bark of Some Species of Spruce, Fir and Pine. Ph.D. Thesis, Institute of Organic Chemistry, Novosibirsk, Russia, 1975; p. 27. (In Russian).

76. Krotova, I.V.; Gulenkova, G.S.; Osmolovskaya, N.A.; Smirnov, R.Y. Utilization of waste from debarking of dark coniferoustree species with the production of antibacterial drugs. SIP Conf. Ser. Earth Environ. Sci. 2019, 315. [CrossRef]

77. Tyukavkina, N.A.; Gromova, A.S.; Lutsky, V.I.; Chubarova, I.S. Fenolokislota bark Pinus sylvestris, P. sibirica and P. abies nephrpolepis. Khimiya Prir. Soyedineniy [Chem. Nat. Compd.] 1974, 1, 78-79. (In Russian)

78. Lutsky, V.I.; Gromova, A.S.; Tyukavkina, N.A. Phenolic compounds of the bark Pinus sibirica and P. sylvestris. Khimiya Prir. Soyedineniy [Chem. Nat. Compd.] 1970, 3, 367. (In Russian)

79. Tyulkova, Y.A.; Ryazanova, T.V.; Eremenko, O.N.; Tarchenkova, T.M. Extractive substances of the water-alkaline extract of pine bark. Khooynyye Boreal'noy Zony [Conifers Boreal Zone] 2013, 31, 101-104. (In Russian)

80. Babkin, V.A.; Ivanova, N.V.; Trofimova, N.N.; Eskova, L.A.; Salyaev, R.K.; Nurminsky, V.N. Research of membranotropic activity of the complex of phenolic compounds and pectin isolated from the bark of larch. In Proceedings of the VIII All-Russian Conference with International Participation "Chemistry and Medicine", Ufa, Russia, 6-8 April 2010; Ufa Institute of Chemistry: Ufa, Russia, 2010; p. 113.

81. Fager, E.P.; Reynolds, A.H. Tannides and coloring substances. Ind. Eng. Chem. Res. 1929, 21, 357. [CrossRef]

82. Freudenberg, K. Tannin-Cellulose-Lignin; Verlag Von Julus Springer: Berlin, Germany, 1933; p. 165, ISBN 978-3-642-47472-9.

83. Wise, L.E.; Jahn, E.C. Wood Chemistry; Books on Demand: New York, NY, USA, 1952; p. 1343, ISBN 978-0-598-94531-0.

84. Orlova, N.Z. Production of Larch Extract and Its Use for Leather Production; The leather industry. Ministry of Light Industry of the USSR: Moscow, Russia, 1974; p. 21. (In Russian)

85. Gavrilov, A.B.; Goryainov, S.I.; Marinichev, A.A.; Gessler, N.N.; Klein, O.I.; Isakova, E.P.; Deryabina, Y.I. Composition of polyphenols in biomaterials of Russian conifers. Khimija Rastit. Syr'ja [Chem. Plant Raw Mater.] 2019, 2, 51-58. (In Russian) [CrossRef]

86. Ryazanova, T.V.; Tok, M.V.; Eremenko, O.N.; Tyulkova, Y.A.; Goncharova, N.V.; Syachinova, N.V.; Dumnova, E.A. Optimization of the process of alkaline extraction of larch bark. In Proceedings of the Leather and Fur in the 21st Century: Technology, Quality, Ecology, Education VI International Scientific and Practical Conference, Republic of Buryatia, Russia, 10-13 August 2010; pp. 118-127. (In Russian).

87. Eremenko, O.N.; Mishura, P.V.; Ryazanova, T.V. Obtaining and ennobling extracts from coniferous bark. Khvoynyye Boreal'noy Zony [Conifers Boreal Zone] 2015, 33, 291-295. (In Russian)

88. Eremenko, O.N.; Mishura, P.V.; Ryazanova, T.V.; Current, M.V. Improving the production of tanning extracts from coniferous bark using alkaline extractants. Vestn. KrasGAU [Bull. KrasGAU] 2015, 2, 90-95. (In Russian)

89. Ryazanova, T.V. Complex Processing of Coniferous Bark with Obtaining Tanning Extracts with Specified Properties. Ph.D. Thesis, Krasnoyarsk State Technological Academy, Krasnoyarsk, Russia, 1999. (In Russian).

90. Goncharova, N.V.; Tok, M.V.; Ryazanova, T.V. The impact of extraction duration on the composition of water-alkali extracts of Siberian larch. Khimija Rastit. Syr'ja [Chem. Plant Raw Mater.] 1998, 2, 75-78. (In Russian)

91. Moskovtsev, N.G.; Chupka, E.I. Influence of monoethanolamine and anthraquinone on the process of alkaline cooking of pine wood. Wood Chem. 1981, 3, 31-33.

92. Chuiko, G.V.; Chupka, E.I.; Nikitin, V.M. Influence of monoethanolamine on wood delignification. Chem. Use Lignin. 1974, 289-293.

93. Yabrov, V.I.; Ryazanova, T.V. Extraction of larch bark with monoethanolamine. In Proceedings of the Young Scientists in Solving Topical Problems of Science, Krasnoyarsk, Russia, 19 May 2017; pp. 207-209.

94. Loskutov, S.R.; Semenovich, A.V.; Permyakova, G.V. Method for Extraction of Biologically Active Compounds from Softwood Bark 2019. Russian Federation Patent 2678683, 30 January 2019. (In Russian).

95. Permyakova, G.V.; Loskutov, S.R.; Semenovich, A.V. Extraction of coniferous bark with the addition of monoethanolamine. Khimija Rastit. Syr'ja [Chem. Plant Raw Mater.] 2008, 1, 37-40. (In Russian)

96. Eremenko, O.N.; Ryazanova, T.V.; Loskutov, S.R.; Dubko, E.I. Extraction of coniferous bark with monoethanolamine. In Proceedings of the Reshetnev Readings. Materials of the XXI International Scientific and Practical Conference Dedicated to the Memory of the General Designer of Rocket and Space Systems, Academician M.F. Reshetnev, Krasnoyarsk, Russia, 8-11 November 2017; pp. 132-133. (In Russian).

97. Senoshova, V.A.; Permyakova, G.V.; Grodnitskaya, I.D.; Pashenova, N.V.; Flaps, S.R. Study of antimicrobial properties and extractive substances of conifers. Sib. Lesn. Zhurnal [Sib. For. J.] 2019, 3, 71-77. (In Russian) [CrossRef]

98. Levdansky, V.A.; Polezhaeva, N.I.; Yeskin, A.P.; Kuznetsov, B.N. Method of Preparing Tanning Extract from Larch Bark 1999. Russian Federation Patent 2124562, 10 January 1999. (In Russian).

99. Yaroshenko, N.A. Influence of temperature and acidity of the medium on ultrafiltration fractionation of tanning solutions. Kozhevenno-Obuvn. Promyshlenost' [Leather-Footwear Ind.] 1989, 8, 41-42. (In Russian) 
100. Yaroshenko, N.A.; Mikhnovsky, A.T.; Zubritskaya, N.M. Fractionation and concentration of spent tanning solutions obtained in the production of leather for the bottom of shoes. Chem. Chem. Tech. [Izv. Vyss. Uchebnykh Zaved. Seriya Khimiya i Khimicheskaya Tekhnologiya] 1988, 31, 80-84. (In Russian)

101. Goncharova, N.V.; Tok, M.V.; Ryazanova, T.V. Ultrafiltration of alkaline extracts of larch bark of Siberian. Khimija Rastit. Syr'ja [Chem. Plant Raw Mater.] 1998, 2, 69-73. (In Russian)

102. Pen, R.Z.; Ryazanova, T.V. Integrated Chemical Processing of Wood. Introduction to Specialty; SibGTU: Krasnoyarsk, Russia, 2012; p. 158.

103. Nguyen, T.M.N. Study of Oxidative Ammonolysis of Common Pine Bark: Pinus sylvestris L. Ph.D. Thesis, St. Petersburg State Forestry Engineering Academy named after S. M. Kirov, St. Petersburg, Russia, 2004. (In Russian).

104. Azarov, V.I.; Boer, A.B.; Obolenskaya, A.B. Chemistry of Wood and Synthetic Polymers: Textbook for Universities; St. Petersburg State Forestry Academy (SPbLTA): St. Petersburg, Russia, 1999; p. 628, ISBN 978-5-8114-1061-3. (In Russian)

105. Aremin, V.M. Anatomical Structure of the Bark of Various Forms Pinus sylvestris L. Izv. Vyss. Uchebnykh Zavedeniy. Lesn. zhurnal [News High. Educ. Inst. For. Mag.] 1984, 3, 19-22. (In Russian)

106. Tyulkova, Y.A. Processing of pine bark to obtain tanning extracts. Ph.D. Thesis, Siberian State Technological University, Krasnoyarsk, Russia, 2013. (In Russian).

107. Tyulkova, Y.A.; Ryazanova, T.V.; Eremenko, O.N. Modification of the All-Union unified method for the determination of tannins in extracts of conifers. SFU Chem. 2014, 7, 298-305. (In Russian)

108. Luneva, T.A.; Kim, N.Y.; Ryazanova, T.V.; Chuprova, N.A. Influence of fungi of the genus Trichoderma on the carbohydrate complex of larch bark of Siberian. Chem. Chem. Tech. [Izv. Vyss. Uchebnykh Zaved. Seriya Khimiya I Khimicheskaya Tekhnologiya] 2006, 49, 88-90. (In Russian)

109. Kim, N.Y. Waste-Free Processing of Bovine Bark of Conifers. Ph.D. Thesis, Siberian State Technological University, Krasnoyarsk, Russia, 2001. (In Russian).

110. Vurasco, A.V.; Zhwirblite, A.K.; Galimova, A.R.; Dricker, B.N. Pulping by Redox-Organosolvent Method; Ural State Forestry University (UGLTU): Yekaterinburg, Russia, 2008; p. 24. (In Russian)

111. Polyutov, A.A.; Pen, R.Z.; Former, A.V. Pulp Technology. Environmentally Friendly Production; Krasnoyarsk Writer: Krasnoyarsk, Russia, 2012; p. 294. (In Russian)

112. Luneva, T.A. Transformation of Tree Bark with a Fungus of the Genus Trihoderma and Obtaining a Biologic Preparation. Ph.D. Thesis, Siberian State Technological University, Krasnoyarsk, Russia, 2008. (In Russian).

113. Makhova, E.G. Cultivation of Fungi of the Genus Trichoderma on Lignocarbohydrate Substrates and Preparation of a Biologic Preparation. Ph.D. Thesis, Siberian State Technological University, Krasnoyarsk, Russia, 2003. (In Russian).

114. Strigunova, A.A.; Eremenko, O.N.; Ryazanova, T.V. Production of modified foam materials using extracts of softwood bark. Khimija Rastit. Syr'ja [Chem. Plant Raw Mater.] 2001, 4, 65-68. (In Russian) 